\title{
The nutritional status of older people attended at Eliza Queiroz Maciel Living Center in Manacapuru, Amazonas, Brazil
}

\begin{abstract}
Purpose: To evaluate the nutritional status of older people attended at Eliza Queiroz Maciel Living Center in Manacapuru, Amazonas, Brazil.

Methods: A descriptive cross-sectional research study approach.

Results: It was found that among the 78 older people participants, older women (83.3\%), widows $(41.0 \%)$, between 65 and 69 years old (37.2\%), mediums brown (46.1\%), Catholics (76.9\%), incomplete elementary education (35.9\%), with 4 to 6 children $(30,8 \%)$, retired (78.2\%), monthly income 1 to 3 minimum wages $(73.1 \%)$, own house $(88.5 \%)$ of masonry $(75.6 \%)$ and with electrical services, piped water, garbage collection and sewage network (48.7\%). It was observed, on average, higher prevalence of overweight by World Health Organization and Lipschitz cut points (39.7\% and 55.1\%), respectively, followed by obesity $(41.0 \%)$ by PAHO cut points, with greatly increased risk in body fat index (BFI) $(53.8 \%)$, waist circumference (WC) $(82.1 \%)$ and increased for waist circumference/hip circumference (WC/HC) $(94.9 \%)$.
\end{abstract}

Conclusions: It can be concluded that $51.1 \%$ of the evaluated older people were overweight, and older women showed a very high risk for diseases associated with overweight $(90.8 \%)$, with the predominance of android fat in older women $(86.2 \%)$.

Keywords: evaluation of nutritional status, obesity, overweight, nutritional transition, ageing, gerontology, health of older people
Volume 4 Issue I - 2020

\author{
Elizama André Gomes Lopes, ' Ana Felisa \\ Hurtado-Guerrero, ${ }^{2}$ José Camilo Hurtado- \\ Guerrero $^{3}$ \\ 'Nursing of Secretaria Estadual de Saúde no Município de \\ Manacapuru, Bachelor in nursing, Universidade do Estado do \\ Amazonas - UEA, Brazil \\ ${ }^{2} \mathrm{PhD}$ in Public Health, Escola de Saúde Pública, Escola de \\ Ciências da Saúde da Universidade do Estado do Amazonas - \\ UEA, Brazil \\ ${ }^{3}$ Post-Doc in Animal behavior (University of Alberta), PhD \\ in Biological Sciences (Entomology) INPA-UFAM, IBEF . \\ Universidade Federal do Oeste do Pará - UFOPA, Brazil
}

\begin{abstract}
Correspondence: José Camilo Hurtado-Guerrero, Universidade Federal do Oeste do Pará - UFOPA, Instituto de Biodiversidade e Florestas - IBEF, Rua Vera Paz, s/n, Salé, Santarém, PA, Brasil, CEP 68040-470, Tel (92) 98405-3863, Email jhocamhu@gmail.com
\end{abstract}

Received: January 17, 2020 | Published: February 19, 2020

\begin{abstract}
Abbreviations: UEA, universidade do estado do amazonas; TCLE, termo de consentimento livre e esclarecido free and informed consent form); AM, Amazonas; IBGE, Instituto Brasileiro de Geografia e Estatística; CEP, comitê de ética em pesquisa (research ethics committee); BFI, body fatness index; WC/HC, waist circumference/ hip circumference; BMI, body mass index; BAI, body adiposity index; PAHO, Pan American Health Organization; WHO, World Health Organization; IPEA, Instituto de Pesquisa Econômica Aplicada; UnATI, Universidade Aberta da Terceira idade
\end{abstract}

\section{Introduction}

Brazil is currently experiencing a rapid nutritional transition, understood as a change in the nutritional profile of a population, where the patterns of distribution of nutritional problems change generating new health aggravations and this transition is characterized by a shift from malnutrition to increased obesity in the general population. ${ }^{1}$ Even though there are different nutritional and economic aspects in a country or region that influences the transition process, the main characteristic changes in lifestyle, such as poor diet and reduction in caloric expenditure and fibre consumption, thus causing the increase in obesity together with the lack of physical activity, mainly in urban regions and constituting one of the major public health problems. ${ }^{2,3}$ Brazil had high rates of malnutrition in the 1970s and 2008, half the adult population was overweight, affecting individuals of all age groups, both sexes and all income levels. ${ }^{3,4}$ The increase in the prevalence of obesity in various subgroups of the population has become an important nutritional complex of global magnitude, with serious social and psychological dimensions, causing a high incidence of cardiovascular diseases, cancer and diabetes influencing the profile of population morbidity and mortality and interfering with the quality of life of the individual, especially the older people. ${ }^{5}$ In recent decades, overweight has reached about $1 / 3$ of the Brazilian adult population and presents a growing trend, with a higher prevalence of obesity among women, including the older, and both sexes, reaching especially the age group between 50 and 65 years. ${ }^{6}$

Brazil is among the countries with the highest prevalence of malnutrition, with significant regional disparities, and the Amazon region and part of the Northeast region have historically been considered as significant endemic hunger zones. ${ }^{7}$ The evolution of the health level among Brazilian regions in 1979, 1990 and 2003 showed that the Northern and Northeastern regions went from type III (low health level, with a high proportion of deaths in children under 1 year and preschool children) to type II (regular health level, where there is a clear increase in the proportion of deaths in individuals aged 50 and over and the lowest proportion of child deaths). ${ }^{8}$ In 2004, the National Research of Food and Nutritional Security, observed greater prevalence of severe food insecurity in the State of Amazonas, being more critical both in the urban area $(44.6 \%)$ and in the rural area $(35.2 \%)^{9}$

The analysis of the nutritional status of Brazilian older people based on data from the Family Budget Survey (2008/2009) found a higher prevalence of overweight in older women $(41.9 \%)$, living in the urban stratum (39.0\%), as well as in the South $(45.1 \%)$ and North $(33.6 \%) .{ }^{10}$ It was also observed, higher prevalence of low weight in older people living in the rural stratum $(26.3 \%)$, being in the Northeast $(23.7 \%)$ and North (18.0\%). The low weight was still more prevalent in older people of yellow (32.1\%) and black (23.6\%). And those who lived alone had higher percentages both of low weight (20.4\%) and overweight $(38.5 \%){ }^{10}$ 
In 2013, overweight and obesity in adults reached $56.9 \%$ and $20.8 \%$ of the population, respectively. ${ }^{11,12}$ Overweight tends to increase with age and happens more rapidly among men, but more slowly among women, with changes in diet and lack of physical activity, it being the main determinants of obesity, which is the most important nutritional disorder in developed countries also affecting developing countries. ${ }^{13}$ Among the older people, there is an alternation of nutritional states of obesity and malnutrition, malnutrition being verified as an independent factor and not as a basic disease and occurring as a consequence of socioeconomic conditions, with the fastest growth rate in the population with lower family income, physiological changes due to age and functional disability. ${ }^{14,15}$ Changes in nutritional status can cause increased morbidity and mortality, as malnutrition contributes to several serious complications, such as infection, wound healing deficiency, respiratory failure, among others. On the other hand, overweight and obesity are risk factors for the emergence of various health conditions, among which ischemic heart disease, hypertension, stroke, among others. ${ }^{16}$ The older people present a strong tendency to develop malnutrition due to the incidence of chronic morbidities and physical changes inherent to advanced age, thus becoming a relevant nutritional deficiency in this population. ${ }^{17}$

Although malnutrition is quite prevalent in the older people and in populations living in extreme poverty, Brazil and other developing countries experiencing a nutritional transition determined by malnutrition see a continuous decrease in cases of malnutrition giving rise to an increasing prevalence of overweight and chronic non-communicable diseases associated with obesity, these diseases being the main causes of death today. ${ }^{18}$ Therefore, the antagonism of temporal trends between malnutrition and obesity constitute one of the characteristics that mark the nutritional transition process in the country and affect not only the health system but also the cultural, social and economic context, making it necessary in the health sector to prioritize strategies aimed at promoting healthy eating and encouraging regular physical activity practices. ${ }^{18}$ In this perspective, this study aimed to evaluate the nutritional status through anthropometric data, as a way to predict the risk of morbidity and mortality and to identify the sociodemographic profile of the older people attended at the Eliza Queiroz Maciel Living Center in Manacapuru, Amazonas, Brazil.

\section{Methods}

Across-sectional descriptive research study approach, with analysis of primary data, was realized with 78 older people attended at the Eliza Queiroz Maciel Living Center in Manacapuru, Amazonas State, whose collection period was from August 2010 to December 2011. A questionnaire was used and an interview carried out to know some socio-demographic characteristics at the place of study, in a reserved place, on days of group activities, before or after the activities. After the student's training period for data collection. The body weight was measured through a KRATOS platform scale, with a precision of 1.25 $\mathrm{kg}$ and a maximum capacity of $150 \mathrm{~kg}$. The scale was gauged before and after the weight was taken. The individuals were weighed, wearing light clothing, barefoot and with lateral distance from the feet. Stature (m) was checked with an inelastic anthropometric tape, with the older people in orthostatic position, with the feet together and barefoot and arms extended downwards. In the anthropometric evaluation for the classification of the body mass index (BMI, the measures of weight $(\mathrm{w})$ and height $(\mathrm{H})$ were used to apply the equation $\mathrm{BMI}=\left(\mathrm{W} / \mathrm{H}^{2}\right)$. For classification of the nutritional status of the older people through BMI three specific cut-off points for older people were employed: proposed by Lipschitz ${ }^{19}$ the Pan American Health Organization (PAHO) ${ }^{20}$ and the World Health Organization $(\mathrm{WHO})^{21}$ (Table 1) was taken as a comparative reference.
Table I Nutritional classification according to body mass index (BMI) cut-off points recommended by Lipschitz, WHO and PAHO for the older people

\begin{tabular}{|c|c|}
\hline BMI Scales $\left(\mathrm{kg} / \mathrm{m}^{2}\right)$ & Nutritional status \\
\hline \multicolumn{2}{|l|}{ LIPSCHITZ (I 994) } \\
\hline$<22$ & Low weight \\
\hline $22-27$ & Eutrophic \\
\hline$>27$ & Overweight \\
\hline \multicolumn{2}{|l|}{ PAHO (200I) } \\
\hline$\leq 23$ & Low weight \\
\hline$>23<28$ & Normal \\
\hline $28<30$ & Pre-obesity or overweight \\
\hline$\geq 30$ & Obesity \\
\hline \multicolumn{2}{|l|}{ WHO (I995) } \\
\hline$<18.5$ & Low weight \\
\hline $18.5-24.99$ & Normal \\
\hline $25.00-9.99$ & Overweight \\
\hline$\geq 30$ & Obesity \\
\hline
\end{tabular}

Source Lipschitz, ${ }^{19}$ 1994; PAHO, ${ }^{20} 2001, \mathrm{WHO},{ }^{21} 1995$

The hip circumference (HC) was measured in centimetres, with the inelastic tape measure surrounding the hip in the area of greater gluteal protuberance between the waist and thigh, without compressing the skin in a horizontal plane. Waist circumference (WC) was also checked in centimetres at the edge of the iliac crest. ${ }^{22,23} \mathrm{WC}$ measurement alone was analyzed from the cut-off points suggested by the $\mathrm{WHO},{ }^{21}$ where for women $\geq 80$ is considered high risk and $\geq 88$ for very high risk; for men $\geq 94$ is considered high risk and $\geq 102$ for very high risk. ${ }^{24}$ The waist circumference/hip circumference (WC/HC) was established by dividing the waist (WC) and hip circumference (HC) values and using the cut-off points for body fat distribution recommended by the WHO. ${ }^{21}$ The body fat index (BFI) was calculated from the following equation: ${ }^{21}$

$$
\begin{gathered}
\text { HFI circumference } \\
\text { Height } * \sqrt{\text { Height }}
\end{gathered}
$$

In the estimation of the prevalence of body adiposity index (BAI) the cut-off points of $35.0 \%$ for females and $25.0 \%$ for males were utilized. In the data analysis, absolute and relative frequency measurements were employed. The database was organized in Microsoft Office Excel, version 2010, and the analysis of variables in Minitab v. $14^{25}$, SPSS v. $20^{26}$ and Epi Info v.6 and 7.1. ${ }^{27}$ The initial project of this work was reviewed by the Research Ethics Committee of the University of the State of Amazonas (UEA), according to opinion $\mathrm{n}^{0} 003 / 11$-CEP/UEA on February 25, 2011. All participants authorized their participation by signing or printing a dactyloscopic on the Term of Free and Informed Consent (Termo de Consentimento Livre e Esclarecido - TCLE), following Resolution 196/96 of the National Health Council (Conselho Nacional de Saúde - CONEP) on research involving human beings. 


\section{Results}

In total, 78 older people participated in the study, older women were predominant $(83.3 \%)$, widows $(41.0 \%)$ and self-defined as married $(46.1 \%)$. The prevailing age was between 65 and 69 years old $(37.2 \%)$, and schooling level was the incomplete elementary education $(35.9 \%)$. The majority of older people were retired $(78.2 \%)$ with monthly income between 01 and 03 minimum wages $(73.1 \%)$ (Table 2).

Table 2 Distribution according to the socio-demographic aspects of the older people attended at the Eliza Queiroz Maciel Living Center in Manacapuru Amazonas, Brazil - 20II

\begin{tabular}{|c|c|c|}
\hline Variables & $\mathbf{n}$ & $\%$ \\
\hline \multicolumn{3}{|l|}{ Sex } \\
\hline Older men & 13 & 16.7 \\
\hline Older women & 65 & 83.3 \\
\hline \multicolumn{3}{|l|}{ Marital status } \\
\hline Single & 3 & 3.8 \\
\hline Married & 23 & 29.5 \\
\hline Widowed & 32 & 41.0 \\
\hline Divorce & 13 & 16.7 \\
\hline Others & 7 & 9.0 \\
\hline \multicolumn{3}{|l|}{ Age group } \\
\hline $60-64$ & 21 & 26.9 \\
\hline $65-69$ & 29 & 37.2 \\
\hline 70-74 & 21 & 26.9 \\
\hline 75 or + & 7 & 9.0 \\
\hline \multicolumn{3}{|l|}{ Race/colour } \\
\hline White & 35 & 44.9 \\
\hline Black & 5 & 6.4 \\
\hline Indian & 2 & 2.6 \\
\hline Yellow & 0 & 0.0 \\
\hline
\end{tabular}

\begin{tabular}{lcc} 
Table continues & & \\
\hline Variables & $\mathbf{n}$ & $\%$ \\
\hline Brown & 36 & 46.2 \\
Schooling and education & & \\
Illiterate & 20 & 25.6 \\
Read and write a note & 13 & 16.7 \\
Incomplete elementary school & 28 & 35.9 \\
Complete elementary school & 5 & 6.4 \\
Incomplete high school & I & 1.3 \\
Complete high school & 9 & 11.5 \\
Incomplete higher education & 1 & 1.3 \\
Complete higher education & 1 & 1.3 \\
Filhos & & \\
$0-3$ & 15 & 19.2 \\
$4-6$ & 24 & 30.8 \\
$7-9$ & 18 & 23.1 \\
\hline I0 or + & 26.9 \\
\hline Hurtado-Guerrero et al. ${ }^{28} ; \mathbf{n}$, sample size; \%, percentage
\end{tabular}

Source Hurtado-Guerrero et al. ${ }^{28} ; \mathbf{n}$, sample size; \%, percentage

The mean weight of the older people was $67.1 \mathrm{~kg}$, the highest mean $(69.7 \mathrm{~kg})$ was found in older men. The stature mean was 1.5 $\mathrm{m}$, with the highest mean found in older males (Table 3). The mean values for other variables were: body mass index (BMI) $(28.8 \mathrm{~kg} /$ $\left.\mathrm{m}^{2}\right)$; body adiposity index (BAI) (36.8); waist circumference (WC) $(99.0 \mathrm{~cm})$; hip circumference $(\mathrm{HC})(103.1 \mathrm{~cm})$ and $\mathrm{WC} / \mathrm{HC}(0.96)$. All these means were higher in older women, except for $\mathrm{WC} / \mathrm{HC}$ (Table 4). Most of the older people were overweight followed by obesity. The prevalence of excess body fat with much-increased risk was $53.8 \%$, being in older men, the highest prevalence (84.6\%). Waist obesity measured by waist circumference showed a muchincreased risk (82.1\%) and $\mathrm{WC} / \mathrm{HC}$ with increased risk (94.9\%). The latter two measures were higher among women (Table 4). In the comparison of the classification of the BMI for the older people in the nutritional assessment. The cut points of the WHO and Lipschitz had a predominance for overweight (39.7\% and 55.1\%). respectively. While the results by the Pan American Health Organization cut points had obesity (41.0\%) (Table 4).

Table 3 Descriptive statistics of the nutritional status of the older people attended at the Eliza Queiroz Maciel Living Center in Manacapuru - Amazonas, Brazil $-2011$

\begin{tabular}{lllllll}
\hline Variables & \multicolumn{2}{l}{ Older women $(\mathbf{n}=\mathbf{6 5})$} & \multicolumn{2}{c}{ Older $\operatorname{men}(\mathbf{n = 1 3})$} & Total $(\mathbf{n}=\mathbf{7 8})$ & \\
\hline & $\bar{x}$ & $\mathbf{S}$ & $\bar{x}$ & $\mathbf{S}$ & $\bar{x} \pm \mathbf{S}$ & Range \\
\hline Weight $(\mathrm{kg})$ & 66.6 & 11.42 & 69.7 & 11.03 & $67.1 \pm 11.35$ & $42.2-94.4$ \\
Height $(\mathrm{m})$ & 1.5 & 0.05 & 1.6 & 0.07 & $1.5 \pm 0.07$ & $1.4-1.7$ \\
BMI $\left(\mathrm{kg} / \mathrm{m}^{2}\right)$ & 29.2 & 4.93 & 26.4 & 3.76 & $28.8 \pm 4.85$ & $21.0-41.4$ \\
BAI & 38.32 & 6.19 & 29.0 & 3.78 & $36.8 \pm 6.81$ & $22.2-53.8$ \\
WC $(\mathrm{cm})$ & 99.6 & 10.49 & 96.2 & 9.61 & $99.0 \pm 10.36$ & $78.0-124.0$ \\
\hline
\end{tabular}


Table continues

\begin{tabular}{lllcccc}
\hline Variables & \multicolumn{2}{l}{ Older women $(\mathbf{n = 6 5})$} & \multicolumn{2}{c}{ Older men $(\mathbf{n = 1 3 )}$} & \multicolumn{2}{c}{ Total $(\mathbf{n = 7 8 )}$} \\
& $\bar{x}$ & $\mathbf{S}$ & $\bar{x}$ & $\mathbf{S}$ & $\bar{x} \pm \mathbf{S}$ & Range \\
\hline $\mathrm{HC}(\mathrm{cm})$ & 104.3 & 10.79 & 97.2 & 6.28 & $103.1 \pm 10.50$ & $87.0-128.0$ \\
$\mathrm{WC} / \mathrm{HC}$ & 0.96 & 0.05 & 0.99 & 0.05 & $0.96 \pm 0.05$ & $0.81-1.07$ \\
\hline
\end{tabular}

$\bar{x}$, arithmetic mean; S, standard deviation; BMI, body mass index; BAI, body adiposity index; WC, waist circumference; HC, hip circumference; WC/HC, waist circumference/hip circumference

Table 4 Comparison of the nutritional status classification of the older people attended at the Eliza Queiroz Maciel Living Center in Manacapuru - Amazonas, Brazil - 20II

\begin{tabular}{|c|c|c|c|c|c|c|c|}
\hline \multirow[b]{2}{*}{ Variables } & \multirow[b]{2}{*}{ Classification } & \multicolumn{2}{|c|}{ Older women } & \multicolumn{2}{|c|}{ Older men } & \multicolumn{2}{|c|}{ Total } \\
\hline & & $\mathbf{n}$ & $\%$ & $\mathbf{n}$ & $\%$ & $\mathbf{n}$ & $\%$ \\
\hline \multirow[t]{3}{*}{ BIM' $^{\prime}$} & Lower weight & I & 1.5 & 1 & 7.7 & 2 & 2.6 \\
\hline & Normal weight & 26 & 40.0 & 7 & 53.8 & 33 & 42.3 \\
\hline & Overweight & 38 & 58.5 & 5 & 38.5 & 43 & 55.1 \\
\hline \multirow[t]{3}{*}{ BMI" } & Normal Weight & 12 & 18.5 & 5 & 38.5 & 17 & 21.8 \\
\hline & Overweight & 27 & 41.5 & 4 & 30.8 & 31 & 39.7 \\
\hline & Obesity & 26 & 40.0 & 4 & 30.8 & 30 & 38.5 \\
\hline \multirow[t]{4}{*}{ BMliii } & Lower weight & 4 & 6.1 & 3 & 23.1 & 7 & 9.0 \\
\hline & Normal weight & 23 & 35.4 & 5 & 38.5 & 28 & 35.9 \\
\hline & Overweight & 10 & 15.4 & 1 & 7.7 & 11 & 14.1 \\
\hline & Obesity & 28 & 43.1 & 4 & 30.8 & 32 & 41.0 \\
\hline \multirow[t]{3}{*}{ BAI } & Normal & 13 & 20.0 & 0 & 0.0 & 13 & 16.7 \\
\hline & Increased Risk & 21 & 32.3 & 2 & 15.4 & 23 & 29.5 \\
\hline & Very Increased Risk & 31 & 47.7 & 11 & 84.6 & 42 & 53.8 \\
\hline \multirow[t]{3}{*}{ WC } & Normal weight & 2 & 3.1 & 7 & 53.8 & 9 & 11.5 \\
\hline & Increased Risk & 4 & 6.1 & 1 & 7.7 & 5 & 6.4 \\
\hline & Very Increased Risk & 59 & 90.8 & 5 & 38.5 & 64 & 82.1 \\
\hline \multirow[t]{2}{*}{$\mathrm{WC} / \mathrm{HC}$} & Low Risk & 1 & 1.5 & 3 & 23.1 & 4 & 5.1 \\
\hline & Increased Risk & 64 & 98.5 & 10 & 76.9 & 74 & 94.9 \\
\hline
\end{tabular}

Source 'Lipschitz, 19 1994; iPAHO,20 200I; ii'WHO,2I 1995; n, sample size; \%, percentage; BMI, body mass index; BAI, body adiposity index; WC, waist circumference; WC/HC, waist circumference/hip circumference

\section{Discussion}

The research of the older people at the Eliza Queiroz Maciel Living Center in Manacapuru, Amazonas, found a predominance of women, low schooling, retirement, income between 01 and 03 minimum wages, corroborating findings in other studies in the country. ${ }^{29,30,31}$ The National Health Survey in 2013 found that $24.4 \%$ of the older people reported participation in organized social activities, with women showing a greater custom of participating in these activities compared to men: $28.1 \%$ and $19.8 \%$, respectively. Fewer percentages were found for people 75 years old or older (19.3\%) and uneducated people $(18.1 \%))^{32}$ Several factors that may explain the higher participation of women in these studies, such as age, empty nest syndrome, the higher life expectancy of women, higher demand for health services due to concern about their health, as well as the mortality risk associated 
with decreased social engagement and its benefits for physical and cognitive functions and well-being. $33,34,35$ Observing that the levels of social engagement increase at the beginning of old age until 75 years old and that the social participation of the older people is related to culture, beliefs, religion, voluntary work, education, sports practice, functional capacity, socially acceptable habits, as well as the opportunities and resources available..$^{36,37,38}$ Thus, the social disengagement observed in older people is largely explained by the theory of socio-emotional selectivity, which explains that in old age, changes in the composition of social networks, in family structure, in work and leisure relationships. and especially in social roles influence social behaviour. ${ }^{39}$

The findings from the study by Bruno et al ${ }^{40}$ highlighted the very low formal schooling average in women, with $66.6 \%$ of the institutionalized older people coming from the interior of the State of Fortaleza, CE were illiterate or had low schooling, showing similar results of this study. The same study showed that the older the age and less schooling, a worse cognitive performance, showing that the educational level is the main variable that influences the cognitive performance in older people. Machado et al. ${ }^{41}$ observed association between schooling and cognitive decline in older people, showing that those with $\leq$ to one year of studies had 3.8 times worse chances of having a cognitive deficit when compared with those with one to four years of studies. Noting that many years of education can make the brain more resistant to the effects of diseases or changes caused by ageing. ${ }^{42}$

It is worth pointing out that most of the population of this study are retired with a predominance of income between 01 and 03 minimum wage. According to the IPEA, ${ }^{43}$ although older women receive the benefit for longer than older men, this one becomes systematically of lower value. In the case of rural retirement, whose value is 01 minimum wages for both sexes, the proportion of older women beneficiaries is much higher than that of older men. And that older men receive 1.5 times higher than older women. However, the income of welfare contributes to the reduction of inequality between older people and both sexes. Considering the population as a whole, it is observed that among older women, inequality is lower among beneficiaries than among non-beneficiaries. In summary, it can be stated that difference goes increasing between older the segment of the population is, already it was found that for every 100 older women there were 80.1 older men being justified by the differential mortality by $\operatorname{sex}^{43}$

There is also a predominance of older widowers $(41.0 \%)$. The fact that was verified in a study by Bento et al. ${ }^{20,19,40,44}$ analyzing nutritional markers among older people with chronic diseases participating in the National Health Survey where there was a higher percentage of widowers. In the study of Graziano et al ${ }^{35,45}$ analyzing cognitive alterations in Parkinson's disease, where most of these were widowers (56.9\%). According to Camarano et al. ${ }^{42,46}$ in Brazil, the dependency ratio between sexes showed in 2010, a feminization of old age, increasing this difference, the older the population segment is, stating that for every 100 women there were 80.1 men, which is justified by the differential mortality by sex.

Based on the comparative percentage distribution of BMI, the population studied presented prevalence of overweight, according to the cutoff points recommended by the $\mathrm{WHO}^{21}$ and Lipschitz. ${ }^{19}$ These results were in concordance with those found by Souza et al. ${ }^{47}$ and Raimundo et al..$^{48}$ when they evaluated the agreement between different classifications of BMI in older people. They showed that according to $\mathrm{WHO}^{21}$ there was the predominance of overweight $(50.4 \%)$ but its results were contrary to that $52.7 \%$ of eutrophic stipulated by Lipschitz. ${ }^{19}$ However, all those results were very close to the findings with older people reported by Palma et al. ${ }^{49}$ using the cutoff points of the BMI, and the NSI parameters, reporting predominance of overweight for older women $(53.8 \%)$ and when analyzed by the $\mathrm{PAHO}^{20}$ method, $45.6 \%$ of obesity for them, corroborating body changes during ageing.

Among the several recommended references for the classification of BMI in older people, those established by $\mathrm{PAHO}^{20} \mathrm{WHO}^{21}$ and Lipschitz ${ }^{19}$ stand out. However, due to the changes in body composition during the ageing process, many criticisms have been considered about the lack of consensus for these cut-off points to classify obesity in older people, which ends up making it difficult to compare the results of national and international researches, which is why we recommend caution when using the cut-off points of BMI for them. ${ }^{47,48,49,50}$ Only the cut-off points proposed by Lipschitz ${ }^{19}$ take into consideration the changes in body composition that occur with ageing with the adult population.

Similar results also were found in different regions of the state of Amazonas with the greater prevalence of overweight in older people: Lemos $^{51}$ investigating older people from UNATi/Manaus, observed $46.6 \%$ of overweight and the evaluations of CC and RCQ showed high risk for developing chronic diseases; Oliveira ${ }^{52}$ evaluating the nutritional profile of older people of the Center of Integral Attention to the Best Age (CAIMI) in Manaus, found $48.8 \%$ of overweight; Mendes et al. ${ }^{53}$ analyzing the nutritional status of adults in the city of Coari, Amazonas, found that the overweight reached $45.0 \%$ and $\mathrm{Lima}^{53}$ reported overweight in older people in a study of anthropometric profile and quality of life in Borba, Amazonas.

The analysis of the nutritional status showed a higher percentage of overweight in older people. These results are in line with the findings of Hurtado-Guerrero, Mainbourg and Hurtado-Guerrero ${ }^{55}$ in a study carried out with indigenous older people in the State of Roraima, where $42.9 \%$ in the 60 to 69 age group were overweight; and Souza et al. ${ }^{56}$ who conducted a comparative study between BMI in older people of Rio Grande do Sul where overweight also prevailed in most of these $(50.4 \%)$ following the classification of the WHO.

However, at the cut-off points determined by Lipschitz ${ }^{19}$ the opposite was true since most of older people were eutrophic $(52.7 \%)$ and this finding was also similar to the predominance of overweight $(54.6 \%)$ found by Cardozo et al..$^{57}$ in Pelotas (RS) and Souza et al..$^{58}$ at a Primary Health Care (50.0\%). However, these results disagreed with the finding of Palma et al. ${ }^{49}$ in their comparative study of BMI in the older people of Palmeiras das Missões (RS) whereby the cut-off points of the PAHO $46.3 \%$ were found with adequate weight. The measures of nutritional status evaluation are one of the first steps to be taken to obtain a partial diagnosis of the nutritional clinical picture of the older people for a possible intervention offered, if opportune..$^{59}$ Among the several methods to evaluate the nutritional status of the older, anthropometric measures are the most used in clinical and population studies. ${ }^{10,60}$

BMI and $\mathrm{WC} / \mathrm{HC}$, when compared to other anthropometric indicators, are widely employed in studies to investigate the greater correlation between overweight, obesity and lipid profile in both sexes becoming important in determining the risk of many diseases. ${ }^{60}$ Overweight is understood as an excessive increase in total body weight, it being a useful factor in predicting health risks associated with obesity. ${ }^{61,62}$ BMI values above normal points are indicators of increased risk of cardiovascular diseases, cancer and diabetes. while 
low weight is usually positively associated with hunger and infectious diseases. ${ }^{63,64}$ In middle age between 50 and 65 years old, overweight is the main nutritional problem because it is associated with chronic degenerative diseases. ${ }^{65,66}$ On the other hand, people over 80 years of age have the greatest problems: thinness and loss of lean mass. Malnutrition in older people contributes to the emergence of diseases such as tuberculosis, obstructive pulmonary diseases, lung and stomach cancer, while overweight contributes to the emergence of cerebrovascular and cardiovascular diseases, diabetes and others ${ }^{65}$ Among the factors that contribute to overweight are: sedentary lifestyles, hypercaloric diet, genetic factors and family history; health conditions such as hormonal problems, anxiety and depression, sex, and age processes when there is a decrease in body mass and energy expenditure. $^{62}$

The increase in chronological age causes changes in body dimension, mainly in height and weight, and nutritional factors are involved in the changes of these two components during ageing. As the years go by, stature decreases due to vertebral compression, narrowing of the discs and kyphosis, affecting women more rapidly due to the higher prevalence of osteoporosis after menopause. ${ }^{67}$ Bodyweight gain that usually begins around 45 to 50 years of age, stabilizing at 70 years of age, beginning to decline until 80 years of age. This weight loss is related to hormonal factors that control hunger and satiety, excessive use of medication, depression, financial stress, diseases among other factors. ${ }^{68,69}$ Among the older people, obesity and overweight have been prominent, with a tendency to produce serious adverse health problems, associated with increased mortality. ${ }^{68,69}$ The older population is particularly prone to nutritional deficiencies for both overweight and underweight10. Malnutrition in older people may result in a deteriorated health, therefore some changes from the physiological process of ageing compromise the intake of nutrients causing malnutrition in the older people. ${ }^{10}$

In the older people studied group, we observed a high prevalence of overweight and draws attention because they participated in physical activities organized by the Living Center. However, low caloric expenditure may be influenced by factors such as nutrition, the lack of regular physical activities, age group, among others. Thus, the predominant result of overweight in older people is a concern mainly due to the association of obesity with the appearance of chronic diseases, which can cause an increase in morbidity and mortality in this group. The nutritional status in older people can be influenced by age, cognition, mobility, autonomy, whether living alone or accompanied, ability to prepare one's own food, income, schooling, the current situation or previous health, presence of co-morbidities, as well as eating habits, beliefs that marked childhood and adolescence and that end up having repercussions in the promotion of nutritional risks and deviations that reflect on the state of health in this stage of life. ${ }^{65}$

Analyzing the Body Adiposity Index (BAI), it was observed that most older women were in increased risk range for the development of chronic non-communicable diseases compared to older men. This finding coincides with other studies realized: $\operatorname{Lemos}^{51}$ with older people attending UnATI/Manaus; Diniz et al. ${ }^{70}$ comparing anthropometric indicators of overweight/obesity in older people residents in rural áreas; Pinheiro and $\mathrm{Cunha}^{71}$ analyzing indicators of body fatness in the older people and Segheto et al. ${ }^{72}$ conducting a nutritional survey in the older people, where older women showed positive association with the body fatness index. Regarding BAI, Sopeña et al. ${ }^{73}$ found $37.6 \%$ in older women and $29.8 \%$ in older men, coinciding with this study. All these findings corroborate with the fact those women presented a higher prevalence of obesity.

The BAI is an index that can be used for the identification of the body adiposity and the possible consequences of overweight and according to Bergman et al. ${ }^{74}$ the BAI shows a better correlation with the percentage of body fat when compared to BMI. A populationbased study that analyzed the factors associated with body fat index, in Brazilian adults, observed that in women there was an average increase of $6.2 \%$ in the BAI about men and concluded that factors such as gender, age, marital status, self-assessment of health, and dissatisfaction with body the image was determinant for the increase in BAI, indicating a strong risk for chronic non-communicable diseases, ${ }^{72}$ such as blood pressure, blood lipid profile, insulin resistance, among other factors. ${ }^{75}$ Although the ageing process cannot be considered synonymous with diseases and disabilities, the current trend is that most of the older people live more is affected by chronic conditions and, generally, these chronic conditions are directly related to greater impairment of the functional capacity of the older people. ${ }^{29,28}$ The use of body fat results in the evaluation of Metabolic Syndrome in older people becomes relevant and studies showed a relationship between accumulated fat tissue and the incidence of adverse metabolic events, noting the higher risk of developing metabolic diseases mediating excess body fat. ${ }^{76,77}$ Thus some authors consider the BAI the best predictor of body fat in older people separately from the BMI. ${ }^{74,77,78}$

The WC in older women constituted a very high risk (90.8\%) for diseases associated with overweight. While older men presented no risk for diseases associated with overweight $(53.85 \%)$. Findings of Kumpel $^{62}$ in the older people attended in the Family Health Program of Passo Fundo (RS) detected that the majority of them presented a high risk for diseases associated with obesity $(67.5 \%)$.

Our results diverged from those found in the study of Marim and Cecilio $^{79}$ with older people in the area of a Family Health Unit in the central region of the city of Marília (SP), showing very high risk for older men $(37.4 \%)$ and older women $(83.5 \%)$, opposite trends to our study for older men that were classified as not at risk for obesityrelated diseases in their majority. The advancement of age causes changes in body composition since the fat-free mass decreases giving way to the fat mass that is stored intra-abdominal and intramuscularly and no longer subcutaneously as in the young adult. ${ }^{67} \mathrm{An}$ increased waist circumference represents a risk for the development of chronic noncommunicable diseases, especially cardiovascular diseases. ${ }^{80}$

The WC is an important indicator of abdominal fat distribution and total body fat changes related to visceral or subcutaneous fat accumulation associated with the ageing process. It takes place differently between older men and older women because some genetic characteristics also contribute to these changes. ${ }^{81}$ Thus, the results of this study suggest a high predisposition of this population to develop chronic noncommunicable diseases, mainly older women. Because, the accumulation of abdominal fat is associated with cardiovascular diseases, which compromises the health and quality of life of these older women, avoiding their engagement in the activities of the Living Center. Increased waist circumference represents a risk for the development of chronic noncommunicable diseases, especially cardiovascular diseases. ${ }^{80}$

Regarding the waist/hip ratio (WC/HC), the older people have been classified according to sex and a higher prevalence of gynoid fat and/or android fat. Gynoid fat is considered to be concentrated in the hip region and presents less risk associated with overweight and 
android fat is concentrated in the abdominal region and presents a higher risk for diseases associated with overweight. It was observed in this study that the highest prevalence of android fat was in older women $(86.2 \%)$ while in older men the predominance of gynoid fat was $53.8 \%$. In the study of Silveira et al. ${ }^{82}$ more prevalence of android fat was observed in older women $(65.5 \%)$ and aged older people as an all (63.6\%). Fogaça et al. ${ }^{83}$ study with Brazilian cardiopaths older people showed high $\mathrm{WC} / \mathrm{HC}$ values in $73.3 \%$ of the older people. As age progresses, there is a decrease in height and weight in both sexes, favouring an increase in $\mathrm{WC} / \mathrm{HC}$ in older women. ${ }^{84}$

The $\mathrm{WC} / \mathrm{HC}$ is one of the main measures utilized in population studies for the diagnosis of central obesity. It is also a predictor of cardiovascular disease risks. ${ }^{85,86}$ Values are variable depending on the measurement techniques, sex and age. The cut-off points used for the general population fat type classification are: $<0.8$ (gynoid) and 0.8 (android) for women; <1 (gynoid) and 1 (android) for men. The lack of specific cut points for the older people population is one of the main limitations of the $\mathrm{WC} / \mathrm{HC}$. The criteria proposed for the general population are used so far. ${ }^{87,88,86}$

In the evaluated group, the predominance of older women with android fat was to be expected since, since with advancing age fat tends to be located in the abdomen. It is different from the population of young adult women who usually accumulate fat in the hip. However, the high number of older women with android fat is a matter of concern, since it represents a strong association with cardiovascular diseases and it may increase the number of morbidities and mortality if specific attention is not given to this population.

\section{Final remarks}

Concerning nutritional status, this study pointed out the high prevalence of overweight in the older people group and the aggravating factors were associated with a very high risk in older women for diseases associated with overweight diagnosed by measuring the waist circumference. Despite being a minority in the group, the older men were considered at no risk for diseases associated with overweight. This high prevalence in older women is of concern since increased waist circumference represents a risk for the development of chronic non-communicable diseases especially cardiovascular diseases. The waist circumference/hip circumference (WC/HC) detected that older women had mostly the android type of fat, while in older men the predominance was the gynoid type fat which confirms that older women were at risk for cardiovascular diseases. Hence the importance of investigating the body composition of the older people and the effects on their health since if specific attention is not given to this population segment the number of older people with morbidities may increase having an impact on the health system with dependence on these services for long periods.

\section{Acknowledgements}

To the elderly and the manager of the Centro de Convivencia do Idoso (Living Center of the Elderly) Eliza Queiroz Maciel of Manacapuru for the direct contribution to the construction of this work. To Universidade do Estado do Amazonas (UEA) and Fundação de Amparo à Pesquisa do Estado do Amazonas (FAPEAM).

\section{Conflicts of interest}

The author declares there is no conflict of interest.

\section{Funding}

None.

\section{References}

1. Kac G, Meléndez V. A transição nutricional e a epidemiologia da obesidade na América Latina. Caderno de Saúde Pública. 2003;19(Suple 1):S4-S5.

2. Souza EB de. Transição nutricional no Brasil: análise dos principais fatores. Cadernos UNiFoA. 2010;13:1-5.

3. Brasil. Pesquisa de orçamentos familiares 2017-2018: primeiros resultados / IBGE, Coordenação de Trabalho e Rendimento. Rio de Janeiro: IBGE, 2019. 69 p.

4. Dias PC, Henriques P, Anjos LA dos, Burlandy L. Obesidade e políticas públicas: concepções e estratégias adotadas pelo governo brasileiro. $\mathrm{Cad}$. Saúde Pública. 2017;33(7):e00006016.

5. Cavalcanti CL, Gonçalves M da CR, Asciutti LSR, et al. Envelhecimento e obesidade: um grande desafio no século XXI. RBCS. 2011;14(2):87-92.

6. Marques APO, Arruda IKG, Espírito-Santo ACG, et al. Prevalência de obesidade e fatores associados em mulheres idosas. Arq Bras Endocrinol Meta. 2005;49(3):441-448.

7. Duarte MG, Sueyla Ferreira, Giseli Minatto, et al. Estado Nutricional de crianças do Baixo Amazonas. J Hum Growth Dev. 2018;28(2):139-147.

8. Pontes RJ, Ramos-Júnior AN, Kerr LRS. Transição demográfica e epidemiológica. In: Medronho RA et al., editors. Epidemiologia. 2.ed. São Paulo: Atheneu; 2009. p. 123-52.

9. Brasil. Ministério da Saúde. Relatório Preliminar de Acompanhamento e avaliação de segurança alimentar de famílias brasileiras, urbano e rural. UNICAMP. 2004. p. 33.

10. Pereira IFS, Spyrides MHC, Andrade LMB. Estado nutricional de idosos no Brasil: uma abordagem multinível. Cadernos de Saúde Pública. 2016;32(5):1-11.

11. IBGE. Instituto Brasileiro de Geografia e Estatística (IBGE). Expectativa de vida do brasileiro sobe para 75,2 anos. 2015.

12. Dias MCG, Aanholt DPJ, Catalani Lam. Sociedade Brasileira de Nutrição Parenteral e Enteral; Associação Brasileira de Nutrologia. Projeto Diretrizes. Triagem e avaliação do estado nutricional. São Paulo: Associação Médica Brasileira/Conselho Federal de Medicina; 2011.

13. Tardido AP, Falcão MC. O impacto da modernização na transição nutricional e obesidade. Revista Brasileira Nutrição Clínica. 2006;21(2):117-124.

14. Fiore EG, Viviane Laudelino, Ana Maria, et al. Nutritional profile of elderly who frequent a health service basic unit. Revista Ciências Médicas. 2006;15(5):369-377.

15. IBGE. Instituto Brasileiro de Geografia e Estatística. Síntese dos Indicadores Sociais. População total e respectiva distribuição percentual, por cor ou raça, segundo as Grandes Regiões, Unidades da Federação e Regiões Metropolitanas. 2009.

16. Acuña K, Cruz T. Assessment of the nutritional status of adults and the elderly and nutritional status of the Brazilian population. Arquivos Brasileiros Endocrinologia e metabologia. 2004;48(3):345-361.

17. Colembergue JP, Conde SR. Use of the Mini Nutritional Assessment in institutionalized elderly. Scientia Medica. 2011;21(2):59-63.

18. Coutinho JG, Gentil PC, Toral N. A desnutrição e obesidade no Brasil: o enfrentamento com base na agenda única da nutrição. Caderno de Saúde Pública. 2008;24(2):S332-S340.

19. Lipschitz DA. Screening for nutritional status in the elderly. Prim Care. 1994;21(1):55-67. 
20. Organización Pan -Americana de la Salud. División de Promoción y Protección de la Salud (HPP). Encuesta Multicentrica Salud, Bien Estar y Envejecimiento (SABE) en América Latina y el Caribe: Informe Preliminar. In: XXXVI Reunión del Comité asesor de investigaciones en Salud; 2001. p. 9-11.

21. World Health Organization (WHO). The use and interpretation of anthropometry physical status: report of a WHO Expert Committee. Geneva; 1995.

22. Sampaio LR. Avaliação nutricional e envelhecimento. Revista de Nutrição. 2004;17(4):507-514.

23. Pereira RA, Sichieri R, Marins VMR. Razão cintura - quadril como preditor de hipertensão arterial. Caderno de saúde pública. 1999;15(2):333-334.

24. World Health Organization (WHO). Obesity: preventing and managing the global epidemic. Report of WHO, Consultation on Obesity, Geneva: WHO.1997.

25. Minitab 14 Statistical Software Academic. State College, PA: Minitab; 2003.

26. IBM Corp. Released 2011. IBM SPSS Statistics for Windows, Version 20.0. Armonk, NY: IBM Corp. 2011.

27. WHO (World Health Organization). The Epi Info. Version. 6.02. A Word Processing, Database, and Statistics System for Epidemiology on Microcomputers. Geneva: WHO. 1994.

28. Hurtado-Guerrero AF, Lopes EAG, Hurtado-Guerrero JC. Functional capacity and sociodemographic conditions of elderly people at the Eliza Queiroz Maciel Living Center of Manacapuru, Amazonas. Brazil. Int J Fam Commun Med. 2019; 3(6):253-261.

29. Alves LC, Beatriz Consuelo, Maria Estrella, et al. A influência das doenças crônicas na capacidade funcional dos idosos do município de São Paulo. Caderno de Saúde pública. 2007;23 (8):1924-1930.

30. Confortin SC, Ione Jayce, Danielle Ledur, et al. Life and health conditions among elderly: results of the Epi Floripa Idoso cohort study. Epidemiolo. Serv. Saúde. 2017;26(2):305-317.

31. Faria CM, Deborah Abuhab, Cintia Leci Rodrigues, et al. Epidemiological profile of elderly included in the elderly people accompanying program (programa acompanhante de idosos - pai). SBGG. 2013;13(4):1-6.

32. IBGE. Pesquisa nacional de saúde: 2013: acesso e utilização dos serviços de saúde, acidentes e violências: Brasil, grandes regiões e unidades da federação / IBGE, Coordenação de Trabalho e Rendimento. - Rio de Janeiro: IBGE, 2015. p. 100.

33. Huxhold O, Miche M, Schüz B. Benefits of having friends in older ages: Differential effects of informal social activities on well-being in middle-aged and older adults. J Gerontol Ser B Psychol Sci Soc Sci. 2014;69(3):366-375.

34. Chiao C, Weng LJ, Botticello AL. Benefits of having friends in older ages: Differential effects of informal social activities on well-being in middle-aged and older adults. J Gerontol Ser B Psychol Sci Soc Sci. 2014;69(3):366-375.

35. Huxhold O, Fiori KL, Windsor TD. Social participation reduces depressive symptoms among older adults: an 18-year longitudinal analysis in Taiwan. BMC Public Health. 2011;10(11):292-300.

36. Donnelly EA, Hinterlong JE. The dynamic interplay of social network characteristics, subjective well-being, and health: the costs and benefits of socio-emotional selectivity. Psychol Aging. 2013;28(1):3-16.

37. Kim J, Yamada N, Heo J, et al. Changes in social participation and volunteer activity among recently widowed older adults. Gerontologist. 2010;50(2):158-69.

38. Morrow-Howell N, Putnam M, Lee YS, et al. An investigation of activity profiles of older adults. J Gerontol Ser B Psychol Sci Soc Sci. 2014;69(5):809-821.
39. Pinto JM, Neri AL. Trajetórias da participação social na velhice: uma revisão sistemática da literatura. Rev Bras Geriatr Gerontol. 2017;20(2):259-272.

40. Bruno R D, Darling KAP, Braga PN, et al. Education, age, and cognitive impairment of elderly residents in long-term institutions. Rev Neurocienc. 2014;22(3):330-336.

41. Machado JC, Ribeiro RCL, Cotta RMM, et al. Declínio cognitivo de idosos e sua associação com fatores epidemiológicos em Viçosa, Minas Gerais. Rev Bras Geriatr Gerontol. 2011;14(1):109-121.

42. Coelho FG de Melo, Vital TM, Novais IP, et al. Cognitive performance in different levels of education of adults and active elderly. Rev Bras Geriatr Gerontol. 2012;15(1):7-15.

43. IPEA. Camarano AA (Org.). Novo regime demográfico: uma nova relação entre população e desenvolvimento? Brasília: IPEA; Rio de Janeiro; 2014. 2013.

44. Bento IC, Souza MAN, Peixoto SV. Associação entre número de medicamentos consumidos e marcadores nutricionais entre idosos com doenças crônicas: Pesquisa Nacional de Saúde (2013). Rev Bras Geriatr Gerontol. 2019;22(1):e180112.

45. Graciano AR, Andressa Meline, Vítor Marcilio, et al. Avaliação nutricional e risco de desnutrição em idosos com demência. Revista Saúde e Pesquisa. 2018;11(2):293-298.

46. Camarano. Brasil. Instituto Brasileiro de Geografia e Estatística (IBGE). Projeção da população 2018: número de habitantes do país deve parar de crescer em 2047. Agência de Notícias. Brasília, maio de 2019. 2017.

47. Sousa KT de, Mesquita LAS de, Pereira LA, et al. Low weight and functional disability in institutionalized elderlyinterns in Uberlândia in the State of Minas Gerais, Brazil. Ciênc. Saúde Coletiva. 2014;19(8):35133520 .

48. Raimundo BCA. Medidas antropométricas adotadas em estudos com idosos residentes em instituições de longa permanência: revisão sistemática. Rev Fisioter S Fun Fortaleza. 2016;5(2):40-52.

49. Palma SW, Sandréli Terezinha, Loiva Beatriz, et al. Comparison of elderly's nutritional status using two cutoff points of classifying body mass index. Saúde (Santa Maria). 2016;(1):147-154.

50. Silveira EA, Kac G, Barbosa LS. Obesity prevalence and associated factors in the elderly in Pelotas, Rio Grande do Sul State, Brazil: obesity classification according to two cutoff points for body mass index. Cad. Saúde Pública. 2009;25(7):1569-1577.

51. Lemos JS. Perfil nutricional de idosos frequentadores da universidade aberta da terceira idade (UNATI) da cidade de Manaus, Am. Mestrado em Ciências de Alimentos, Universidade Federal do Amazonas. 2012. p. 59.

52. Oliveira SAG. Perfil alimentar e nutricional dos idosos e formulação de complemento nutricional a partir de frutos produzidos no Estado do Amazonas. Programa de Doutorado em Biotecnologia. Universidade Federal do Amazonas. 2013. p. 98.

53. Mendes AV, Mundim SM, Tavares BM. Estado nutricional de praticantes de caminhada e corrida da cidade de Coari - Am. Rev Brasileira de Nutrição Esportiva. 2012;6(34):283-291.

54. Lima A. Perfil Antropométrico, Aptidão Funcional e Qualidade de Vida em Adultos Idosos de Borba Amazonas, Brasil. Programa de Atividade Física e Desporto, Universidade da Madeira. 2016. p. 174.

55. Hurtado-Guerrero AF, Mainbourg ET, Hurtado- Guerrero JC. Condições nutricionais de um grupo de idosos indígenas no Distrito Sanitário Leste. In: Coimbra JR et al., editors. Epidemiologia e saúde dos povos indigenas no Brasil. Rio de Janeiro: Editora FIOCRUZ; Rio de Janeiro: ABRASCO, 2005. p. 260.

56. Souza R, Fraga JS de, Gottschall CBA, et al. Avaliação antropométrica em idosos: estimativas de peso e altura e concordância entre classificações de IMC. Rev Bras Geriatr Gerontol. 2013;16(1):81-90. 
57. Cardozo NR, Patricia Abrantes, Andreia Morales, et al. Nutritiona status of elderly attended by family health unit in the city of Pelotas-RS. BRASPEN J. 2017;32(1):94-98.

58. Souza YP, Bezerra A de M, Fabrício NP, et al. A qualidade de vida de idosos com obesidade ou sobrepeso. RBCS. 2018;22(2):155-164.

59. Kim H, Hirano H, Edahiro A, et al. Sarcopenia: Prevalence and associated factors based on different suggested definitions in community-dwelling older adults. Geriatrics \& Gerontology International. 2016;16(1):110 122.

60. Oliveira MAM, Fagundes RLM, Moreira EAM, et al. Relación de indicadores antropométricos con factores de riesgo para enfermedad cardiovascular. Arquivos Brasileiro de Cardiologia. 2010;94 (4):478-485.

61. Oliveira DV de, Thiago Petronilio, Fabiana Cristina, et al. O tipo de exercício físico interfere na frequência da prática de atividade física, comportamento sedentário, composição corporal e estado nutricional do idoso. Revista Brasileira de Nutrição Esportiva. 2019;13(77):3-16.

62. Kumpel DA, Adriana de Camargo, Dalva Maria, et al. Obesidade em idosos acompanhados pela estratégia de saúde da família. Texto contexto enfermagem. 2011;20(3):471-477.

63. Souza LJ de, Gicovate NC, Chalita FEB, et al. Prevalência de obesidade fatores de risco cardiovascular em Campos. Arq Bras Endocrinol Metab. 2003;47(6):669-676.

64. Cabrera MAS, Jacob Filho W. Obesidade em idosos: prevalência, distribuição e associação com hábitos e co-morbidades. Arq Bras Endocrinol Metab. 2001;45:494-501.

65. Cervi A, Franceschini SCC, Priore SE. Análise crítica do uso do índice de massa corporal para idosos. Revista de Nutrição. 2005;18(6):765-775.

66. Campos MAG. Estado Nutricional e Antropometria em idosos: revisão da literatura. Revista Médica de Minas Gerais. 2007;17(3/4):111-120.

67. Brasil. Ministério da Saúde. Secretaria de Atenção à Saúde. Departamento de Atenção Básica. Estratégias para o cuidado da pessoa com doença crônica: obesidade / Ministério da Saúde, Secretaria de Atenção à Saúde, Departamento de Atenção Básica. Brasília: Ministério da Saúde, 2014. p. 212.

68. Associação Brasileira para o Estudo da Obesidade e da Síndrome Metabólica Diretrizes brasileiras de obesidadel ABESO - Associação Brasileira para o Estudo da Obesidade e da Síndrome Metabólica. $-4^{\text {th }}$ ed. São Paulo, SP. 2016.

69. Fechine BRA, Trompieri N. O processo de envelhecimento: as principais alterações que acontecem com o idoso com o passar dos anos. Revista Inter Science Place. 2012;20(1):1-27.

70. Diniz KO, Rocha SV, Santos CA. Body mass index and adiposity measures in elderly residents in rural areas. Estud. Interdisc. Envelhec. 2015;20(2):399-411.

71. Pinheiro EES dos, Cunha CO de. Body adiposity indicators in eldery. Nutr Clín Diet Hosp. 2016;36(4):106-110.

72. Segheto W. Fatores associados e índice de adiposidade corporal (IAC) em adultos: estudo de base populacional. Ciênc. Saúde Coletiva. 2018;23(3):773-783.
73. Sopeña VS, Bruna Celestino, Andreia Morales, et al. Using of the anthropometrics indicators to evaluate of body adiposity in the elderly in Southern Brazil. BRASPEN J. 2018;33(1):39-42.

74. Bergman RN, Stefanovski D, Buchanan TA, et al. A Better Index of Body Adiposity. Obesity. 2011;19(5):1083-1089.

75. Wang S, Liu Y, Li F. et al. A novel quantitative body shape score for detecting association between obesity and hypertension in China. BMC Public Health. 2015;15(7):1-9.

76. Eckel RH. A syndrome metabólica. The Lancet. 2010;375:2.

77. Morais, KBDuarte de. Capacidade preditiva de indicadores de adiposidade sobre o risco cardiometabólico em idosos de Viçosa (MG). [Dissertação]. Programa de Pós-graduação em Ciência da Nutrição. 2014. 86p.

78. López AA, Cespedes ML, Vicente T, et al. Body Adiposity Index Utilization in a Spanish Mediterranean Population: Comparison with the Body Mass Index. PLoS ONE. 2012;7(4):35281.

79. Marin MJS, Cecílio LCO. Necessidades de saúde de idosos de uma Unidade de Saúde da Família. Revista Brasileira de Gerontologia. 2009;12(1):63-76.

80. Fuzaro Junior G, Elisangela Gisele, Raiana Lídice, et al. Alimentação e nutrição no envelhecimento e na aposentadoria. In: Costa JLR et al., editors. O que vamos fazer depois do trabalho? Reflexões sobre a preparação para aposentadoria. São Paulo: Cultura Acadêmica, 2016, p. 103-116.

81. Espinosa G, Porto F, Gurgel JL. Influence of Exercise on Anthropometric Indicators of Cardiovascular Risk in Elderly Women. International Journal of Cardiovascular Science. 2015;28(4):290-297.

82. Silveira EA, Vieira LL, Souza JD de. Elevada prevalência de obesidade abdominal em idosos e associação com diabetes, hipertensão e doenças respiratórias. Ciênc. Saúde Coletiva. 2018;23(3):903-912.

83. Fogaça LT, Cristian Roncada, Ana Rita, et al. Evaluation of waist-hip ratio in subjects with cardiovascular disease. Revista Brasileira de Ciências da Saúde. 2014;12(40):2-7.

84. Falsarella GR, Gasparotto LPR, Coimbra IB, et al. Envelhecimento e os fenótipos da Composição Corporal. Revista Kairós Gerontologia. 2014;17(2):57-77.

85. Pinto LLT, Isnanda Tarciara, Samara Carolina, et al. Relação cinturaquadril e fatores associados em idosos residentes em municípios de pequeno porte. Congresso Nacional de envelhecimento humano. 2014. p.

86. Rezende FAC. Índice de massa corporal e circunferência abdominal: associação com fatores de risco cardiovascular. Arq Bras Cardiol. 2006;87(6):728-734

87. Correa MM. Razão cintura-estatura como marcador antropométrico de risco à saúde: estudo de base populacional em adultos e idosos brasileiros. Programa de Pós-graduação em Epidemiologia. Faculdade de Medicina, Universidade Federal de Pelotas. 2016. p. 222.

88. Silva JL, Marques APO, Leal MCC, et al. Fatores associados à desnutrição em idosos institucionalizados. Rev Bras Geriatr Gerontol. 2015;18(2):443-451. 